\title{
Economic Development, Growth and Welfare
}




\section{ECONOMICS TODAY}

Edited by Andrew Leake

The Economics Today series surveys contemporary headline topics in applied economics. Each book in the series is written by an expert in the field in a style that is fluently readable. It serves the student of introductory economic principles while also making the subject accessible to a more general reader. The series embraces the problem-solving skills of the new generation of students and stresses the importance of realworld issues and the significance of economic ideas.

\section{Published}

Andrew Leake: The Economic Question

Jean-Louis Barsoux and Peter Lawrence: The Challenge of British Management

Andy Beharrell: Unemployment and Job Creation

Frank Burchill: Labour Relations

Kenneth Durham: The New City

S.F. Goodman: The European Community (2nd edn)

Charles Smith: Economic Development, Growth and Welfare

Jenny Wales: Investigating Social Issues

John Wigley and Carol Lipman: The Enterprise Economy

Margaret Wilkinson: Taxation

\section{Forthcoming}

Nigel Healey and Mark Cook: Growth and Structural Change Ian Hodge and Diane Dawson: Choices for the Environment Kent Matthews: Macroeconomics and the Market John Wigley: The Rebirth of Russia

\section{Series Standing Order}

If you would like to receive future titles in this series as they are published, you can make use of our standing order facility. To place a standing order please contact your bookseller or, in case of difficulty, write to us at the address below with your name and address and the name of the series. Please state with which title you wish to begin your standing order. (If you live outside the UK we may not have the rights for your area, in which case we will forward your order to the publisher concerned.)

Standing Order Service, Macmillan Distribution Ltd, Houndmills, Basingstoke, Hampshire, RG21 2XS, England. 


\section{ECONOMIC DEVELOPMENT, GROWTH AND WELFARE}

Charles Smith

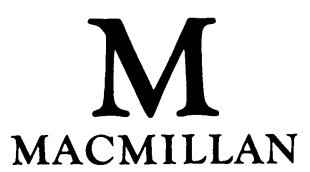




\section{(C) Charles Smith 1994}

All rights reserved. No reproduction, copy or transmission of this publication may be made without written permission.

No paragraph of this publication may be reproduced, copied or transmitted save with written permission or in accordance with the provisions of the Copyright, Designs and Patents Act 1988 , or under the terms of any licence permitting limited copying issued by the Copyright Licensing Agency, 90 Tottenham Court Road, London W1P 9HE.

Any person who does any unauthorised act in relation to this publication may be liable to criminal prosecution and civil claims for damages.

First published 1994 by

THE MACMILLAN PRESS LTD

Houndmills, Basingstoke, Hampshire RG21 2XS

and London

Companies and representatives

throughout the world

ISBN 978-0-333-59268-7

ISBN 978-1-349-23385-4 (eBook)

DOI 10.1007/978-1-349-23385-4

A catalogue record for this book is available from the British Library.

Typeset by Cambrian Typesetters, Frimley 
Dedicated to: Francis Archie Smith, Mary Louise Quibell, José Brocca Ramón, and Rosa García López; my grandparents, mis abuelos 
Make John Lennon's dream come true . . .

It's the least we can do.

Song by Gerry Murray (Brandon Publishers), performed by Christie Moore (WEA Records). 


\section{Contents}

List of Tables, Figures and Boxes $\quad x$ Acknowledgements xiii

Preface xiv

List of Abbreviations xvii

1 The World and its Welfare 1

Income, Growth and Welfare 2

2 Development: Economic and Human 14

Economic Development 15

Human Development? 16

How and Why does Development Take Place? 22

Development Policy 28

3 Population Growth: Threat or Opportunity? 29

Supply and Demand 29

Population Pressures 30

The Prophet of Doom 32

The Case for Population Growth 34

The Case Against 35

The Dependency Ratio 36

Social Attitudes 37 
viii Contents

Population Control 37

Children in the Population 38

The Development Trap 40

The Malthusian Trap 41

4 Can we Cure Poverty?

Who are the Poor? 43

Too Poor to Live? 45

How to Cure Poverty? 45

Aid and Absolute Poverty 46

Poverty and the Environment 46

Relative Poverty 47

Income and Wealth 48

How Can We Measure Income Inequality? 50

Why do Poorer Countries Seem Prone to Disaster? 53

Disease and Famine 55

The Rural Poor and Empowerment 58

Poverty and the Role of Women 59

5 Feeding the World 63

Nutrition and Cash 63

Terms of Trade 64

The Banks 65

The Advisors 65

Local Effects 66

Land-ownership $\quad 67$

The Green Revolution 68

Land Degradation 70

Cash Crops and the MDCs 70

Alternatives to Cash Crops 73

What Can the MDCs Do? 75

What Can the LDCs Do? 76

Food and Water 76

6 Industrialisation - The Key to

Development? 78

The Stages of Growth 78

Structural Change 80 
The Dual-Sector Development Model 82

Criticism of the Lewis Model $\quad 87$

The Myrdal Theory 88

The Todaro Model 88

The Role of Government 89

Rural versus Urban: A False Dichotomy? 90

Appropriate Technology $\quad 90$

Multinational Enterprises $\quad 94$

MNEs and LDCs 95

7 Life in a Trading World 98

Industry and Trade $\quad 98$

Export-Orientation (Outward Strategy) 99

Import-Substitution (Inward Strategy) 100

Trade and Welfare 101

Why does Trade Take Place? 108

Free Trade versus Protectionism 111

Trade and the LDCs 113

8 The Debt Crisis 124

Currency and Exchange Rates 124

International Saving, Investing and Borrowing 128

Aid 141

9 Government, Externalities and the

Environment 147

Macroeconomic Policy 147

Microeconomic Policy 149

Types of Planning 149

Externalities 151

Natural Monopolies, Public Goods and Merit Goods 152

Centralisation and Decentralisation 153

Areas of Special Government Concern 154

Some Conclusions 156 


\section{List of Tables, Figures and Boxes}

Tables

2.1 The Human Development Index and Other Indicators for Selected Countries, $1992 \quad 18$

2.2 Main HDI Rankings, 199320

2.3 Education as Investment: Economic Rates of Return on Education 25

3.1 The World's Largest Cities, 1985 and $2000 \quad 31$

4.1 Poverty in LDCs 44

8.1 Aid Receipts 145

9.1 The Effects of Externalities 152

\section{Figures}

1.1 A Production Possibility Curve 6

2.1 Spending on Education 24

3.1 World Population Projections 30

3.2 Infant Mortality Rate (children under 5) 40

3.3 Main Causes of Death of Children under 5, in Developing Countries, $1990 \quad 41$

4.1 World Income Distribution: A World Lorenz Curve, $1990 \quad 50$

4.2 World Income Distribution: Income Disparities over Time 52 
4.3 Projected New HIV Infections each year 56

4.4 Daily Calorie Supply per Head as a Percentage of Requirements 57

5.1 Supply and Demand for Sugar 67

5.2 Price Stabilisation through Buffer Stocks 73

5.3 Tobacco Sales in MDCs and LDCs 74

6.1 Percentage Shares of Output in MDCs 81

6.2 The Lewis Model 86

7.1 International Trade and Economic Welfare: A Closed Economy 102

7.2 International Trade and Economic Welfare: An Open Economy 103

7.3 The Welfare Effects of a Tariff 105

7.4 The Welfare Effects of an Import Quota 107

7.5 The Welfare Effects of a Government Intervention Purchasing Scheme 108

7.6 The Welfare Effects of a 'Setaside' or Production Quota Scheme $\quad 110$

7.7 Supply and Demand - Commodities and Manufactures 114

7.8 Regional Blocs and World Trade 116

7.9 Sri Lanka Tea Exports 122

8.1 Net FDI Flows to Developing Countries 129

8.2 Net FDI Flows from OECD Investors, 1980-89 130

8.3 Three Major Sources of FDI Flows to Development Countries 132

8.4 FDI Flows to Developing Countries: Regional Trends, 1980-89 133

8.5 East Asia and the Pacific: The Principal Sources of Direct Investment Flows, 1980-89 134

8.6 East Asia and the Pacific: The Principal Destinations of FDI Flows 135

8.7 Latin America and the Caribbean: The Principal Sources of Direct Investment Flows, 1980-89 136

8.8 Latin America and the Caribbean: The Principal Destinations of Direct Investment Flows 137

8.9 World Bank Lending (as at 30 June 1991) 138

8.10 Money Flows between the IMF, World Bank and LDCs 144 
xii List of Tables, Figures and Boxes

\section{Boxes}

6.1 Case Study: Finance in Mauritius 83

6.2 Case Study: The Durable Car Company 93

7.1 Case Study: The Tin Collapse 118

8.1 An Example of an IMF Programme 131

8.2 Examples of World Bank Loans 138

8.3 The Debt Boomerangs 142 


\section{Acknowledgements}

I wish to thank Stephen Rutt and the publishing team for supporting this project, and Andrew Leake for his encouragement and advice. All errors and omissions are my own responsibility.

I particularly wish to record my thanks to Julia, Sally and Matthew Smith for their patience and understanding; and my apologies to Charles and Olga Smith, Glyn and Peg Kingdom, and anyone else I might have neglected during my hours at the word processor.

The author and publishers wish to thank the following copyrightholders and sources of statistical information for permission to reproduce copyright material: Bank of England, Organisation for Economic Coopertation and Development, Oxfam, United Nations Development Programme, United Nations Children's Fund, World Bank, World Health Organisation, Finance and Development, New Internationalist. Every effort has been made to contact copyright-holders for permission to reproduce material in this book, but if any have been inadvertently overlooked, the publishers would be pleased to make the necessary arrangement at the earliest opportunity. 


\section{Preface}

Development economics has a reputation for being a particularly difficult branch of an already difficult subject. This is partly due to the fact that textbooks on development tend to be either encyclopaedic works for degree students, or in-depth studies of narrow topics aimed at the high-level specialist. In contrast, this book is meant to be an 'entry-level' text, suitable for economics candidates at A-level (where development is likely to increase in importance as syllabuses adopt an 'issues based' approach); and also suitable for equivalent examinations such as the International Baccalaureate (where development is already an important part of the curriculum). Additionally, it should be useful to students of related subjects, such as geography; to undergraduates embarking on a study of development; and to the general reader.

It is therefore hoped that this little book will have something of value for young economists who wish to be shown ways in which their chosen subject is of vital importance in the real world; for teachers who wish to give higher priority to development topics; and for readers of all ages who wish to take an informed interest in these important issues.

In a book of this size it is not possible to address all development issues in detail, and so some selection has taken place. An attempt has been made to address those aspects of development which relate to the themes of 'growth' and 'welfare'; and to discuss issues which give the student of introductory economics a chance to see 
some applications of basic economic theory, and to use the language of economics in a development context.

Readers wishing to continue their interest in development with further reading can safely afford to avoid most of the British tabloid press, where reporting of foreign news tends to range in standard from non-existent to appallingly xenophobic. It is no wonder that so many readers of most examples of this genre appear to have difficulty in regarding themselves as Europeans, let alone as world citizens. Of the broadsheet papers, The Financial Times can be singled out for its regular in-depth surveys of particular countries, and The Independent, The Observer and The European often focus on particular development issues. The 'EG' supplement of the education section of The Guardian very often contains a great deal of useful information, of interest to both teachers and students. Probably the most efficient way of keeping in touch with development issues is to follow the themes presented in the weekly newspaper, The Economist and the monthly New Internationalist, and I think that it is fair to say that these journals view matters from rather different political stances.

Somewhat in advance of anticipated changes in the A-level economics syllabuses, the editors of The Economic Review and Economics and Business Education (formerly Economics) show commendable willingness to carry articles covering development topics. It is to be hoped that this healthy trend will continue, and that students will be encouraged to follow the new opportunities to study development economics which should become available in the near future.

Among official publications I would strongly recommend the World Bank's World Development Report and the United Nations Development Programme's Human Development Report, whose findings feature strongly in parts of this book. These are annual publications, and something which makes them particularly interesting is the way in which they usually deal with a particular theme each year.

On BBC Radio 4, programmes such as Analysis and From Our Own Correspondent sometimes touch on development issues. While there are occasional emotional appeals at the time of some obvious disaster, mainstream television largely ignores the less developed countries (LDCs). The so-called 'minority' channels are honourable exceptions. It is particularly worth seeking out 


\section{xvi Preface}

relevant Open University programmes on $\mathrm{BBC} 2$, and any repeats of the excellent One World series screened on Channel 4 during the 1992 Rio Summit Conference on the Environment.

A book of limited size and scope has to be selective in its approach. During the important gestation period, I found the aforementioned sources of great value in helping me to select some themes and issues as being particularly worth highlighting in this book.

I hope that students using this book will find themselves just a little better-equipped to follow development issues, wherever they are discussed, with a critical awareness.

Bridgend, Wales

CHARLES SMITH 


\section{List of Abbreviations}

bn billion

m million

CAFOD Catholic Fund for Overseas Development

CAP Common Agricultural Policy (EC)

EBRD European Bank for Reconstruction and

Development

EC European Community (European Union)

EFTA European Free Trade Association

ERM Exchange Rate Mechanism

FAO Food and Agricultural Organisation

FTA Free Trade Areas

GATT General Agreement on Tariffs and Trade

GDP gross domestic product

GNP gross national product

HDI Human Development Index

HDR Human Development Report

HYV high-yielding varieties (of cereal)

IBRD International Bank for Reconstruction and Development

IDA International Development Association

IFC International Finance Corporation

IFAD International Fund for Agricultural Development

IMF International Monetary Fund

IPPF International Planned Parenthood Federation 
ITC International Tin Council

LDCs less developed countries

MDCs more developed countries

MEW measure of economic welfare

MFA Multi-Fibre Agreement

MFN most favoured nation

MIGA Multilateral Investment Guarantee Agency

MNE multinational enterprise

NAFTA North Atlantic Free Trade Area

NIC newly industrialised countries

NSP net social product

OECD Organisation for Economic Cooperation and Development

OPEC Organisation of Petroleum Exporting Countries

OXFAM Oxford Committee for Famine Relief

PPC production possibility curve

PPP purchasing parity

SDR Special Drawing Rights

TVs traditional varieties (of crops)

UNCTAD United Nations Conference on Trade and

Development

UNDP United Nations Development Programme

UNICEF United Nations Children's Fund

US United States (adjective)

USA United States of America (noun)

VER voluntary export restraint

WDR World Development Report

WHO World Health Organisation 